\title{
Approach to the formulation of a National Information Policy for South Africa
}

\author{
Ingrid Henrici \\ Department of Information Science, University of Pretoria \\ ingrid.henrici@debeersgroup.com*
}

\begin{abstract}
Received: $26^{\text {th }}$ November 2002
Revised: $16^{\text {th }}$ August 2003

This paper reports on guidelines produced by a postgraduate study on an approach towards the formulation and implementation of a National Information Policy in South Africa. Topics examined include the reasoning why SA needs a NIP, the proposed philosophical approach that should be applied, proposals for the principles that should underpin a NIP in South Africa and the issues that a South African National Information Policy should consider.
\end{abstract}

Keywords: National Information Policy; Policy formulation; Policy principles; South Africa

*The opinions expressed are those of the author. De Beers Consolidated Mines Ltd. does not accept any responsibility.

\section{Introduction}

Considering South Africa within an African context one conjures up the imagery of poverty, drought, and underdevelopment with little or no information technology and unreliable and inadequate telecommunications infrastructure. Yet South Africa finds itself in a unique position in the world, geographically, politically and strategically. The spirit of dialogue and consensus building has brought together stakeholders from all sectors of society to consider a wide range of issues. South Africa's information technology sector is also better developed than most countries facing similar developing problems. Various sources (Van Audenhove, 1999 and Economic Commission for Africa, 1996) maintain that information and communication technologies (ICT) can find application within a development context. In order for this to take place an agenda for action focussing on necessary preconditions, skills, support needed and legislative and regulatory changes must be produced. Essentially this is the aim of a National Information Policy.

\section{Methodology}

A study completed by this author (Henrici, 200I), posed the question whether existing National Information Policy (NIP) formulation guidelines are sufficient and relevant to enable a developing country such as South Africa (SA) to formulate and legislate a meaningful NIP. An exploratory study was done through a literature survey. The initial strategy collected as much data as possible using traditional bibliographical database searches but these were later augmented and replaced by several successful Internet searches. A theoretical background study of Information Policies was undertaken. This theoretical study was augmented by the use of a case study as a point of reference. The case study was based on Malaysia's efforts at formulating its integrated National Library and Information Policy as reported by Chaudhry (1993) and Rehman (1996).

An overview and critical analysis of past proposals for formulating a NIP by Non-Government Organisations was also undertaken. These include efforts by:

I.The Canadian International Development Research Centre (IDRC) as discussed by Akhtar and Melesse (1994) and Lundu (1995).

2.The United Nations Educational, Scientific and Cultural Organisation (UNESCO) as presented by Montviloff (1990) and discussed by Rehma(11996).

3. The efforts of the National Information Technology Forum (NITF) as offered in its draft document "Towards an Information Society policy for South Africa" (1997, draft 5).

It was subsequently found that the above guidelines are outdated and not appropriate for the unique conditions found within South Africa presently. The further purpose of the research was to develop a framework of NIP guidelines suitable for South Africa. Thus applying what was gained from the theoretical investigations and case study, guidelines for an own approach towards the formulation and implementation of a NIP were produced. A synopsis of these suggested guidelines is presented in this article. This includes the proposed philosophical approach, the principles that should underpin a NIP in SA and the relevant issues that a South African NIP should address. This discussion is introduced by reasons why SA needs a NIP. 


\section{Why South Africa needs a NIP}

In general policies are needed to provide guidelines within a framework to assist those in authority to allocate resources for the planned and better co-ordinated development of infrastructures, in this case specifically information infrastructures. A NIP is therefore required to ensure the harmonious implementation and operation of information resources, services and systems. According to the Economic Commission for Africa (I999) ICT's are remaining at the centre of global social and economic transformations. Having a NIP therefore implies more effective participation in regional and international information systems and networks.

Probably the most universally important reason for a NIP is because of the rapidly changing ways in which information is produced, packaged, marketed and distributed. These changes have an enormous impact on various aspects of South Africa's economy and society. A NIP is therefore needed to cope with the following major challenges:

- The external pressures put onto South Africa by international governments.

- The internal challenge of societal and economic renewal.

- Pressures for change emanating from the new information technologies themselves, and

- The external challenge of the open global economy.

Furthermore, according to the Economic Commission for Africa (1999), although early African NIP's were broader in conceptualisation, evidence shows that they lacked comprehensiveness in terms of contents and coverage. The SA applicable reasons can be divided into six main categories namely: economic, governmental, cultural, educational, developmental, and technological reasons.

I. Economic reasons. A NIP provides the framework within which priorities can be established to govern the allocation of resources among different groups of users and sectors. A NIP is also necessary to transform the government into the desired vision of an efficient and responsive instrument of delivery and empowerment.

2. Governmental reasons. The NIP should stipulate guidelines for overcoming problems, which may arise because of the country's geographical and political situation. Information is the life-blood of participative democracy and transparent administration. South Africa's new constitution entrenches the right to privacy in terms of communication infringement, and each citizen has the freedom of expression. Everyone has the right of access to any information held by the state and any information that is held by another person that is required for the exercise or protection of any rights.

3. Cultural reasons. The South African society is very complex in that there are First and Third World components, both are dependent on information. A NIP is thus required so that all sectors of the information community in South Africa can develop in a co-ordinated, planned and optimal manner.

4. Educational reasons. Investing in people as the productive and creative core of the economy is one of the six pillars of the government's growth and development strategy. The potential of advanced information technology must be harnessed in the service of South Africa's people to support education, the provision of household services, and social development. For this to happen, information literacy is a skill that needs to be acquired.

5. Developmental reasons. A wealth of information is said to speed up the tempo of development if critical activities such as decision-making, planning and management are based on sound information (van Audenhove, 1999 and Economic Commission for Africa, 1996).

6. Technological reasons. With the emergence of the so-called Information Society, a new dimension was brought to the subject in that information itself is seen as a strategic resource. The elaboration of IT policy is a major determining factor in setting up the underlying supporting infrastructure and enhancing the optimal use of technology to advance the development of Third World countries.

As reported by Cillié \& Roos (1996), Nassimbeni (1994), Walker (1993) and Zaaiman \& Roux (1989) numerous discussions, workshops and conferences have been held in South Africa to draw up NIP frameworks and principles. Nevertheless to date no formal policy document or broad strategic policy plan to arrive at the vision of an Information Society has been drawn up. Roos (1998) remarks that some constraints in South Africa relate to the current inadequate national information infrastructure, funding and the need for an implementation strategy. On the other hand the delay can be attributed to the phenomenon that many initiatives are weighed down by excessive discussion. This prevents meaningful action and wastes valuable resources. An example of such an opportunity lost is the Information Society and Development Conference in 1996, which failed to act as a catalyst to initiate a policy development process.

\section{Proposed guidelines for a NIP in South Africa}

The fact that decision making and planning necessitates information of all kinds makes it imperative that a policy statement be adopted. In addition, inadequacies in SA's current legislative and regulatory frameworks necessitate the creation of a policy that will not only be adaptable to change, but which should be an active agent to facilitate change itself. Change is inevitable and should therefore be welcomed. 


\section{Philosophical approach}

The formulation of a NIP is based on a certain philosophy about how policy development is approached. Previous policy developments in South Africa can be said to have been highly government-regulated with a plan-directed approach aimed primarily at economic and industrial development of a minority. This means that industries that were related to government for promotion as a means to achieve government-determined ends were targeted. Conversely, the freemarket approach is where the government's role is limited to regulating the private sector to achieve social goals such as pollution control or equal opportunity, and to providing public goods such as education and infrastructure (Dedrick and Kraemer, 1995:32). When choosing a fresh philosophical approach for South Africa, the free-market approach should not be chosen simply because of the past failings of the government-regulated approach. A balance needs to be found between the two extremes, this is where Angelides and Agius's (2000) eight scenarios distinguishing the amount of government interference or not, can be applied. These eight scenarios are:

I. "Dominance" (high consultation, high regulation and high use)

2. "Nanny" (high consultation, high regulation and low use)

3. "Laissez-faire" (high consultation, low regulation and high use)

4. "Host" (high consultation, low regulation and low use)

5. "Coercion" (low consultation, high regulation and high use)

6. "Laissez-passer" (low consultation, high regulation and low use)

7. "Minimalism" (low consultation, low regulation and high use)

8. "Lacklustre" (low consultation, low regulation and low use).

According to Angelides and Agius (2000:63), as a result of the recent liberalisation of many telecommunications markets in the world, scenarios one, two, five and six are unlikely to prevail for much longer. Therefore they should not be regarded as long-term solutions. Within contemporary South Africa democracy is based on transparency, therefore the process of consultation is of fundamental importance. It ensures that the creation of government policy takes place by means of participation by citizens, stakeholders and interested parties. This also ensures that the policy enjoys the widest possible support and acceptance by the people and stakeholders. It is thus proposed that South Africa should consider either option three or four, which involve high consultation. More specifically option three with high use is preferred. To ensure credibility and confidence in the policy, the government itself must make high use of its own policies.

\section{National Information Policy principles for South Africa}

Having identified and studied the broad information policy principles as found in the literature (Montviloff, 1990; Wild 1996 and Roos 1998) it can be put forward that most types of principles are based on the general principles of information itself. The national information policy principles and their implications for South Africa follow:

I. Information is an economic resource. It is therefore not free and must be managed just like any other resource. This implies clear committed management responsibility and user accountability for the efficient and effective utilisation of information in order to improve productivity.

- A policy should be realistic and affordable in terms of the South African economy and should form part of a government financing mechanism ensuring all initiatives are prioritised, approved and funded in a co-ordinated manner.

- Co-ordination of services and integration of products must be promoted. Efficiency, productivity and effectiveness in the workplace will improve, as well as decision-making through timeous access toaccurate information.

- ICT's can have a dramatic impact on economic and social development via the use of the information technology revolutionto meet development goals.

- Information technology is increasingly central to economic growth which is a prerequisite to addressing the health, environment, governmentand other challenges facing developing countries according to Bonjawo (2002).

- Benefits if ICT usage include improved flow of information, job creation, economic integration, improved market efficiency and education.

2. Globalisation of Information Communications Technologies. Technology plays a catalysing role necessary for competitiveness in the global economy. This implies allocation of national resources for the development and maintenance of a flexible communications infrastructure that supports the free flow of information to all citizens.

- The policy must be supported by a cost-effective infrastructure in terms of the South African economy.

- Common concepts, standards, procedures and formats must be negotiated.

- Design of open and modular systems should be supported.

- Information technology should be made available to allow for access to as well as the sharing and communication of information.

3. Rights of ownership. Personal authors own their own works whereas government information is seen as custodial ownership.

- The policy must encourage the use of local and indigenous knowledge, expertise and technology.

4. Privacy and confidentiality. People have a right to privacy of personal and private information as well as corporate confidentiality and security of strategic information. This must be weighed up against the protection of information from malicious and unauthorised use and change. 
- The central government should be run as a government enterprise by means of open practices to provide the best serviceso government itself and to all its citizens.

5. Information (access) is a basic foundation of democracy. Information resources should be deployed to support democracy. Certain information is instrumental to the exercising of basic human rights therefore people should have the right of access to this information.

- The information resources of the country should be deployed to support democracy.

- The government should establish a forum for focussing government service and management concerns in respect of delivery of quality services to the citizens.

- The government should foster a work environment that promotes co-ordination of services, integration of products and recognises the value of and supports ongoing consultation with and education and training for employees, managers and citizens.

- It should address the needs of disadvantaged communities and encourage use of local knowledge, expertise and technology.

6. Standards for information access and dissemination are encouraged to ensure access through compatibility, quality and accuracy. These standards should be established and accepted by all relevant stakeholders (government, business and education).

- The government must support the constitutional requirements for access to government-related information.

- The government should establish a central repository where current, consistent and co-ordinated core data and metadata would be available for access and dissemination.

3 National Information Policy issues

A NIP essentially covers the issues of the information life cycle from generation to destruction. Information-related issues identified in the literature have been analysed and structured according to Moore's (1996) three levels of analysis.

To review, Moore's (1996) three levels of analysis include,

- The industrial policy level, relating to the development of an information sector on a national scale. This concerns the development of the information industry as an industrial sector in its own right, which has, at the same time, an important facilitating role as a supplier of information to other industrial sectors.

- The organisational level is concerned with the ways in which organisations use information as a resource to increase productivity, efficiency and competitiveness.

- The social level is concerned with information needs and information provision related to individuals and social groups.

For example, questions of citizenship and participation are addressed.

Consequently the table below is an own interpretation of issues that a NIP should address structured according to Moore's (1996) analytical matrix. The key issues identified are based on the following viewpoints, Bender, Kadec and Morton (199I:14); Boon (1992:5); Carpinter (1991:21); Cheveri and Trump (1996:380); Cronin (1987:133); Kisiedu (1988:24); McClure (1996:215); Mchombu and Miti (1992:146, 161); Montviloff (1990); Nusseir (1996:67); Oppenheim, (1996:4 I5-420); Rehman (1996: I86-190); Rowlands (1996); See (1999); South Africa (199|b:7I); Stone (1998); Wild and MnCube (1996: 187), and Zwangobani (1988:158-159).

Table I Policy issues that need to be addressed by a National Information Policy

\begin{tabular}{|c|c|c|c|}
\hline \multicolumn{4}{|c|}{ The Information Policy Matrix } \\
\hline & Industrial & Organisational & Social \\
\hline 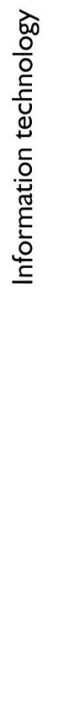 & $\begin{array}{l}\text { Systems must be user friendly, } \\
\text { standardised and compatible to ensure that } \\
\text { information is easily accessible and usable. } \\
\text { Data and information must be transformed } \\
\text { into usable knowledge, which must be user } \\
\text { friendly and relevant to its target } \\
\text { population. Information must be provided } \\
\text { in a timely fashion } \\
\text { Utilise latest and appropriate technology to } \\
\text { facilitate the processing, manipulation, } \\
\text { storing and retrieval of information. } \\
\text { Develop a system for information } \\
\text { processing collaboration and inter-linking } \\
\text { between NIP information resources and } \\
\text { institutions. }\end{array}$ & $\begin{array}{l}\text { Governments stimulate the development } \\
\text { of local value-added information services. } \\
\text { Infrastructure issues include information, } \\
\text { communication and service networks as } \\
\text { well as the policies that govern them. } \\
\text { Aspects of information infrastructure } \\
\text { provision include basic telecommunications } \\
\text { infrastructure and telematics services, } \\
\text { management structures and regulatory } \\
\text { frameworks. } \\
\text { Information Technology as the panacea of } \\
\text { information and knowledge gaps and } \\
\text { problems. Most people are under the } \\
\text { misconstrued notion that IT is an all-in-one } \\
\text { solution, forgetting that it is merely an } \\
\text { enabling tool. }\end{array}$ & $\begin{array}{l}\text { Domestic exploitation of the economic } \\
\text { opportunities of the information } \\
\text { infrastructure. }\end{array}$ \\
\hline
\end{tabular}


Table I Policy issues that need to be addressed by a National Information Policy

\begin{tabular}{|c|c|c|c|}
\hline \multicolumn{4}{|c|}{ The Information Policy Matrix } \\
\hline & Industrial & Organisational & Social \\
\hline 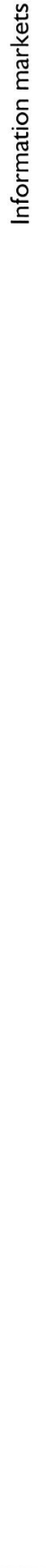 & $\begin{array}{l}\text { The information services sector requires } \\
\text { reliable and up-to-date market information } \\
\text { on trends in consumer demand and } \\
\text { behaviour. } \\
\text { In order to provide information at the point } \\
\text { of use and make use of conventional } \\
\text { market mechanisms, the way the } \\
\text { information market works must be } \\
\text { understood. }\end{array}$ & $\begin{array}{l}\text { Organisations require market information } \\
\text { about export opportunities to justify large } \\
\text { investment costs, and potential for } \\
\text { expansion and where and why products } \\
\text { fail. } \\
\text { The effect of changes in social habits and } \\
\text { consumption patterns have affected and } \\
\text { been affected by the information market. } \\
\text { Develop simpler products with easier } \\
\text { training for new users. } \\
\text { Policies to expand markets in order to } \\
\text { reduce costs of information products. } \\
\text { The market for information is global, with } \\
\text { markets in the East growing rapidly. } \\
\text { Establish a basic level of information } \\
\text { resources to which the individual has a } \\
\text { "guaranteed" right. } \\
\text { The issue of authentic and legal versions of } \\
\text { government documents in electronic } \\
\text { formats. } \\
\text { commercial sectors can lead to increased } \\
\text { productivity. } \\
\text { Information can extend market } \\
\text { penetration, lead to new products and add } \\
\text { higher value to products and services. } \\
\text { Also leads to the development of systems } \\
\text { and procedures, e.g. to make it easy to buy } \\
\text { information from networks. } \\
\text { Which government publications should } \\
\text { continue to be issued in hardcopy, and } \\
\text { which in soft copy in the context of their } \\
\text { timeliness, time-sensitive nature and their } \\
\text { market. }\end{array}$ & $\begin{array}{l}\text { Consumers need information about } \\
\text { services that are on offer, including new } \\
\text { local providers being established, } \\
\text { evaluations and consumer tests to exercise } \\
\text { choice in an informed way. } \\
\text { Some social information can be provided } \\
\text { through conventional markets using the } \\
\text { price system to achieve balance between } \\
\text { supply and demand. }\end{array}$ \\
\hline
\end{tabular}


Table I Policy issues that need to be addressed by a National Information Policy

\begin{tabular}{|c|c|c|c|}
\hline \multicolumn{4}{|c|}{ The Information Policy Matrix } \\
\hline & Industrial & Organisational & Social \\
\hline 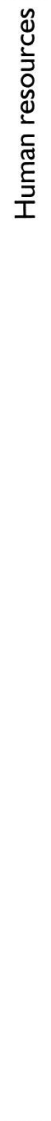 & $\begin{array}{l}\text { Shortages of skills holds up the } \\
\text { development of new products, therefore } \\
\text { changing skills requirements must be } \\
\text { monitored to identify shortages of skills in } \\
\text { areas and communicate this to education } \\
\text { and training facilities. This influences the } \\
\text { National employment policy. } \\
\text { Need for policies to support appropriate } \\
\text { curriculum development. }\end{array}$ & $\begin{array}{l}\text { Without appropriately educated and } \\
\text { trained staff there will be loss of quality. } \\
\text { Consider the role and skill requirements of } \\
\text { intermediaries and information brokers, in } \\
\text { terms of educational requirements. } \\
\text { Speed of change requires need for constant } \\
\text { retraining. } \\
\text { Technology offers the potential for } \\
\text { developing new forms of work. } \\
\text { Organisations need to consider the } \\
\text { implications for skill requirements, and the } \\
\text { impact on personal and community } \\
\text { relations. } \\
\text { In the work environment, there is a need } \\
\text { for people who can process large amounts } \\
\text { of information, adding value by synthesising } \\
\text { and simplifying it. } \\
\text { Changes in the work environment imply } \\
\text { other changes such as different } \\
\text { management strategies. } \\
\text { There is need for a shift in attitudes } \\
\text { towards information among the providers } \\
\text { of goods and services. }\end{array}$ & $\begin{array}{l}\text { To improve information handling skills as } \\
\text { society becomes more information } \\
\text { intensive, focus is placed on critical-thinking } \\
\text { skills. } \\
\text { Education and training issues encompass } \\
\text { the definition of approaches to education } \\
\text { and training in a world where the impact of } \\
\text { ICT's has altered many of the traditional } \\
\text { signposts of the profession. } \\
\text { There is a need for a workforce capable of } \\
\text { adapting to the new generation of tools. } \\
\text { Social problems need to be overcome so } \\
\text { that people can help others to use } \\
\text { information. } \\
\text { Education at all levels needs to be } \\
\text { improved and supplemented by work- } \\
\text { related skills. } \\
\text { Human resource programmes, especially } \\
\text { education, training and research and } \\
\text { development programmes, must be } \\
\text { consistent with the current information } \\
\text { environment. }\end{array}$ \\
\hline
\end{tabular}


Table I Policy issues that need to be addressed by a National Information Policy

\begin{tabular}{|c|c|c|c|}
\hline \multicolumn{4}{|c|}{ The Information Policy Matrix } \\
\hline & Industrial & Organisational & Social \\
\hline 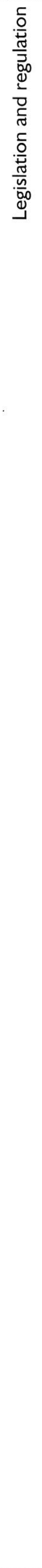 & 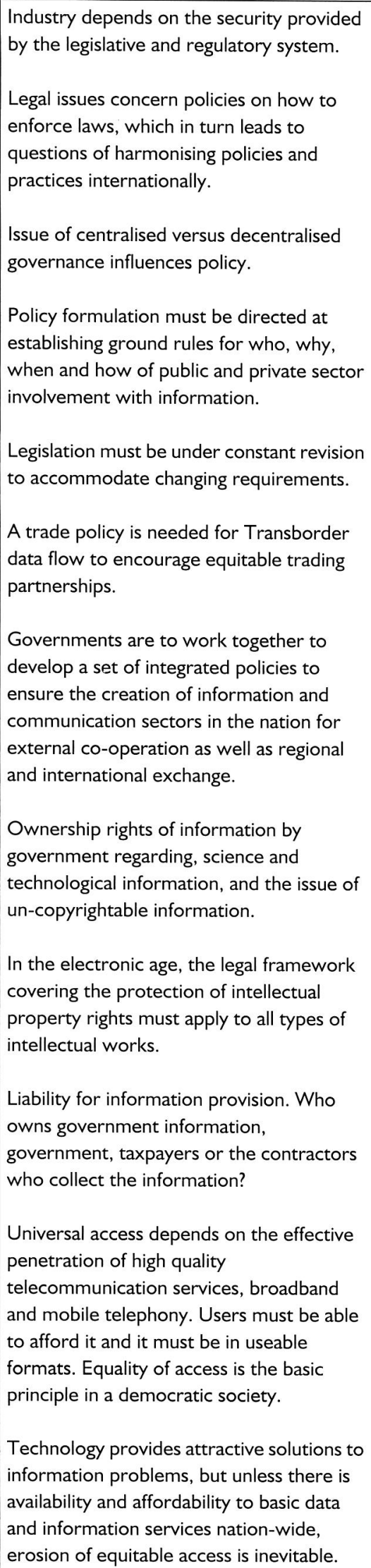 & $\begin{array}{l}\text { Need for legislation regarding the security } \\
\text { of electronic transactions as a consequence } \\
\text { of changes in data protection and privacy } \\
\text { laws, to prevent fraud and protect } \\
\text { commercial value. } \\
\text { Increased penetration of information } \\
\text { reinforces the need to protect personal } \\
\text { data and provide privacy and security } \\
\text { Preservation archives and records } \\
\text { management. In the desire to digitise } \\
\text { information and offer it electronically, } \\
\text { there is a lapse in policies and procedures } \\
\text { on their preservation and conservation. } \\
\text { Concerns are due to the creation of } \\
\text { historical information in electronic format } \\
\text { and that those historical documents will be } \\
\text { lost. } \\
\text { Co-ordination and organisation issues are } \\
\text { the most effective means of maximising } \\
\text { meagre resources at all levels of operation. } \\
\text { Information searches must be conducted to } \\
\text { avoid duplication of effort. } \\
\text { A multi-faceted approach to information } \\
\text { gathering and dissemination must be } \\
\text { utilised. } \\
\text { On-going summative evaluation of } \\
\text { information deliverables must be } \\
\text { conducted. } \\
\text { information sharing must be encouraged }\end{array}$ & $\begin{array}{l}\text { There is a need for independent media } \\
\text { control and ownership to ensure that } \\
\text { objective information from independent } \\
\text { sources is readily available. This implies a } \\
\text { broadcasting policy and licensing. } \\
\text { Freedom to publish or disseminate } \\
\text { information, which complies with } \\
\text { accepted obscenity, public decency, race } \\
\text { relation, slander laws or may seem } \\
\text { subversive or offensive against public } \\
\text { order. } \\
\text { Each country should take stock of existing } \\
\text { policies and assess the current situation vis } \\
\text { a vis achievable, to ensure that there are } \\
\text { policies to define the framework, agenda } \\
\text { and strategy that the country wants and } \\
\text { can adopt. It should not be acceptable for } \\
\text { legislators to pass laws that are } \\
\text { unintelligible. } \\
\text { Government should convene groups to } \\
\text { Preate an information "bill of rights". } \\
\text { Pafeguards against controls on access to } \\
\text { information should be built and maintained, } \\
\text { this includes the issues of sensitive but } \\
\text { unclassified information and of restrictions } \\
\text { Nor entitlements without information. } \\
\text { democratic processes, therefore legal } \\
\text { rights to information (access) must be } \\
\text { established. It is the public service } \\
\text { providers' duty to provide information. } \\
\text { Information issues become most closely } \\
\text { associated with political and cultural } \\
\text { traditions, e.g. a culture of freedom to } \\
\text { information versus a culture of official } \\
\text { secrecy. } \\
\text { developed about what information belongs } \\
\text { in the public domain and by what means it } \\
\text { should be delivered. }\end{array}$ \\
\hline
\end{tabular}


In summary, the general scope of a NIP covers the acquisition, organisation, management and dissemination of information, which may be in any format, e.g. printed, graphic, audio, electronic or other media. There are many issues that need to be addressed by a NIP. Which issues South Africa chooses to address will depend not only on the global issues but also on the choices it makes in response to its very particular development situation.

\section{Conclusions}

One of the major challenges facing the present South African government is the achievement of a balance between maintaining stable economic growth and redressing the inequalities of the past. The broad philosophical outlook guiding South African public life also plays an important role. A view that despite the various and distinct cultures and other differences that make up our society, the South African nation is united in its diversity, and a shared vision that information communication technologies can help to overcome some of the legacies of the past, will bring SA a long way towards the successful development of the nation. Practitioners however have to satisfy the information requirements of a very heterogeneous society, composed of many cultural, language and ethnic groups. Infrastructures and operational characteristics decide whether policies, however well formulated, are likely to succeed. The successful implementation of a NIP therefore requires the existence of an effective national information infrastructure, adequate skilled manpower, supportive facilities, and appropriate financial resources. The establishment of a relevant policy will thus ensure that South Africa becomes and remains an information/ knowledge rich country.

\section{References}

AKHTAR, S. and MELESSE, M. 1994. Africa, information and development: IDRC's experience. Journal of Information Science 20(5):3/4-322.

ANGELIDES, M.S. and AGIUS, H.W. 2000. Eight scenarios of national information superhighway development. Journal of Information Technology 15:53-67

BENDER, D. R, KADEC, S. T, and MORTON, S. I. 199I. National information policies: strategies and the future. SLA Occasional paper series no.2 Washington: SLA.

BONJAWO, J. 2002. Bridging the digital divide between Africa and the rest of the world. [online] Available from http:// allafrica.com/stories/printable/20020I l60488.html [accessed I 9 January 2002]

BOON, J.A. 1984. A national information policy and the South African institute of librarianship and information science. South African Journal of Library and Information Science 52(I): $15-22$

BOON, J.A. 1992. Information policy in a new South Africa. In: Proceedings of the conference on library and information services for future development of Southern Africa 6-8 May 1992 Pretoria.

CARPINTER, A. 199I. Managing data, knowledge and know-how: information policy issues for the 1990s. Wellington: National Library of New Zealand.

CHAUDHRY, A. S. 1993. Information policies in Saudi Arabia and Malaysia. Information Development 9(4) December: 228-233.

CHEVERI, J. F. and TRUMP, J. F. 1996. Information policy. Changing lanes on the government information highway. The Journal of Academic Librarianship. September 1996:378-381.

CILLIÉ, R. M. and ROOS, A. 1996. Towards a national LIS policy framework for South Africa. Meta-Info Bulletin. July 5(4): I I-16.

CRONIN, B. 1987. Transatlantic perspectives on information policy: the search for regulatory realism. Journal of Information Science. (I3): 129-138.

DEDRICK, J. and KRAEMER K.L. 1995. National technology policy and computer production in Asia-Pacific countries. The Information Society II (I): 29-58

ECONOMIC COMMISSION FOR AFRICA. 1996. African Information Society Initiative (AISI). An action framework to build Africa information and communication infrastructure.

ECONOMIC COMMISSION FOR AFRICA. 1999. Developing national information and communications infrastructure (NICl) policies, plans and strategies: the "why" and "how". 1999. [online] Anonymous paper presented to the first meeting of the Committee on Development Information (CODI) of the Economic Commission for Africa, Addis Ababa, Ethiopia, 28 June 2 July 1999. Available from http://www.bellanet.org/partners/aisi/codipap2.htm [accessed 7 March 2000] http:// www.africacomputing.org/references/eca.htm [accessed 10 October 2000]

HENRICI, I. 200I. Theoretical foundation for the formulation of a National Information Policy for South Africa. Dissertation submitted in fulfilment of the requirements for the degree Master of Library and Information Science, Faculty of Human Sciences, University of Pretoria, Pretoria. (Unpublished)

KISIEDU, C. 1988. National information policies, plans and systems in Sub-Saharan Africa. In: Akhtar, S. (Ed.) 1988. National information and informatics policies in Africa. Report and proceedings of a regional seminar. Addis Ababa, Ethiopia. 28 November I December 1988. Ottawa: International Development Research Centre and Pan African Documentation and information system: I-68.

LUNDU, M. C. 1995. Formulation and implementation of a National Information Policy (NIP) in the context of an African environment: Issues and strategies. In: Evans, J. A. (Ed.) Planning for Library Development, Third world perspectives. Dalhousie Univ.: Halifax, Nova Scotia. (22):49- 70.

MCCLURE, C. R. 1996. Libraries and federal information policy. Journal of Academic Librarianship. 22(3):214-I8.

MCHOMBU, K. J. and MITI, K. 1992. Formulation of national information policies in Africa: some unlearnt lessons. International Information and Library Review (24): I39-I7I. 
MILLER, J. 1996. National information policy framework. In: Empowering communities in the information society, Helderfontein estates, Glen Ferness, Fourways, South Africa 15-17 May 1996.

MONTVILOFF, V. 1990. National information policies: a handbook on the formulation, approval, implementation and operation of a National Policy on Information. Paris: UNESCO

MOORE, N. 1996. Policy issues in the multimedia age. Journal of Information Science 22(3): 213-218

NASSIMBENI, M. 1994. Constructing national library and information policy options for South Africa within the framework of educational transformation. Journal of Librarianship and Information Science. 26 (3): 149 - 156.

NATIONAL INFORMATION TECHNOLOGY FORUM. 1997. Towards an Information Society Policy for South Africa. A proposal from the National Information Technology Forum, draft 5.

NUSSEIR, Y. 1996. National case study- Jordan In: Empowering communities in the information society, Helderfontein estates, Glen Ferness, Fourways, South Africa 15-17 May 1996.

OPPENHEIM, C. 1996. An agenda for action to achieve the information society in the UK. Journal of Information Science. 22(6):407-421.

REHMAN, S. U. 1996. Information policies for developing nations: a framework for analysis applied to Malaysian and Indian information policies. Libri. (46): 184-195.

ROOS, A. 1998. Input paper by the Dept. of Arts, Culture, Science and Technology for the Information Society Conference [online] Available from http://www.systems.co.za/nitpf/g7/dpinput.htm [accessed 12 August 1998]

ROWLANDS, I. 1996. Understanding information policy: concepts, frameworks and research tools. Journal of Information Science. 22(1):13-25.

SOUTH AFRICA. Department of National Education. 1991. The Structure of the South African system of libraries and information NATED o2-109 (9//03). Pretoria: National Advisory Council on Libraries and Information. South Africa: Dept. of National Education. National Education Policy.

STONE, M.B. 1998. National Information Policy [online] Available from http://sn.apc.org/ecis/martha.htm [accessed 2I August 1998]

VAN AUDENHOVE, L. 1999. South Africa's Information Society Policy: An overview. Proceedings of the conference on Moral and legal challenges of the information age 24-25 May 1999 University of Pretoria.

WALKER, C. M. 1993. From Carnegie to NEPI: ideals and realities. Mousaion. I / (2):58-83.

WILD, K. 1996. The RDP's national information project. Empowering communities in the information society: conference proceedings. Helderfontein Estate, Glen Ferness, Fourways, SA 15-17 May 1996.

WILD, K. and MNCUBE, S. 1996. Information and communication policy: issues and initiatives in South Africa. Information Technology for Development. (7): 183-193.

ZAAIMAN, R. B. and ROUX, P. J. A. 1989. The use of libraries for the development of South Africa: findings and recommendations. South African Journal of Library and Information Science. 57(I):8-15.

ZWANGOBANI, E. 1988. National informatics policies in Sub-Saharan Africa. IDRC Report and proceedings of a regional seminar, Addis Ababa, Ethiopia 28 November-I December 1988:151-174. 